\title{
Islamic Work Performance of Muslim Employees
}

\author{
Harinoto \\ Department of Economics and Business \\ Universitas Kanjuruhan Malang \\ Malang, Indonesia \\ harinoto@unikama.ac.id
}

Anwar Sanusi

Department of Economics and Business

Universitas Merdeka Malang

Malang, Indonesia

professor@anwarsanusi.net

\author{
Christea Frisdiantara \\ Department of Economics and Business \\ Universitas Kanjuruhan Malang \\ Malang, Indonesia \\ christeafrisdiantara@unikama.ac.id
}

\author{
Boge Triatmanto \\ Department of Economics and Business \\ Universitas Merdeka Malang \\ Malang, Indonesia \\ Boge.triatmanto@unmer.ac.id
}

\begin{abstract}
This study aimed to analyze the linking of Islamic work ethos to the performance of employees through organizational commitment in a city government. The types of research include explanatory research, by developing survey methods, using questionnaires with city government employees as the respondents. The population of this study are all civil servants who are Muslims and enter the work unit. From the number of employees are taken samples with Slovin formula and $\mathbf{7 \%}$ alpha. Then, it obtained 178 people as the research samples by using proportional random sampling technique. The data analysis techniques were using descriptive analysis and structural equation modeling (SEM). The results prove that the commitment of the organization is reflected by the commitment of sustainability, with the ethos of communication among employees and superiors. Organizational commitment plays a strategic role in mediating the work ethos of Islam on the performance of employees that is reflected in their communicative nature by building the cooperation in harmony.
\end{abstract}

Keywords: $\quad$ Islamic work ethic; employee performance; dan organizational commitment

\section{INTRODUCTION}

Municipal government is a part of the system of state governance, whose existence becomes an important pillar of employee performance to make a professional, responsible, honest, and fair civil servant. Every period, the accountability performance of city government is evaluated to maintain a good employee performance. The emerging and interesting phenomenon to be observed is the city government's efforts in building the Islamic behavior by encouraging the prayers on time regulation. This contains a very noble call and moral message, as conveyed by Agustian [1] that the pillars of Islam of the praying rules is an effort to build a personal and social toughness in dedicating to God. The basic value of personal toughness is honesty, responsibility, visionary, discipline, cooperation, fair and caring. Followed by 6 (six) moral principles based on the Pillars of Faith is to build an emotional and Islamic intelligence, in the hope of creating an 'ihsan' (good deeds) heart that is appreciated by God [1]. It results the domino effect of a mental revolution to drive change, by establishing an Islamic work ethic that encourages organizational commitment and affects the employee performance, and to maintain specified integrity.

This study aims to understand the employee performance of the mental factors of Islamic work ethos and organizational commitment factor. Mentally the Islamic work ethos is a genuine effort, mobilizing all assets, thoughts and remembrances to actualize oneself as the God's servants and as are part of the best society (khaira ummah), and make the personal or group of Muslims [2]. The better the work ethos of Islamic by building harmonious cooperation is, the better the perception of organizational commitment. This research model was developed by Hayati and Caniago [3], Salahudin, et.al. [4] and Begum [5] that focused on the influence of Islamic work ethos on the employee performance. It can be explained that the better the work ethos of Islamic performance is, by building a better cooperation among the employee in harmony, the better the perception of the employee performance. The same research model was also done by Mitroff [6] that the work ethos of Islamic perspectives is more likely to improve the more compact team work. Furthermore, it is able to grow the awareness of the other employee's needs. Kale [7] stated that the essence of the Islamic work ethos seeks to live a more meaningful life, there is a transcendental process (conscience) that affirms the passion and transcends the ego, and produces the awareness to develop a more balance life. Giacalond, Paul and Jurkiewics [8] stated that the work ethos of Islamic perspective in the workplace is more sensitive to corporate in a social performance, the leader behavior is more expressed to the employees, and its existence could give more intensive communication and care, so they are aware to improve performance together. A research conducted by Hayati and Caniago [3] found that the work ethos of Islamic has a significant effect on the employee performance. Islam as the foundation, the foundation of human life that influence the shapes of the universal system value. Ali and Al Owaihan [9] stated that the Islamic work ethos stands for the fulfillment of life, worship and economic motives in everything, because the 
'door of luck' of God is coming from the economic activity. Some of the results of this study were strengthened to the existence of work ethos of Islamic perspective on the employee performance, that the performance of the employees was better when they used an Islamic work ethos as a basic foundation of work.

The employee performance is understood from the Islamic work ethos that the work is a worship, the achievement is beautiful, and the work should cover all kind of acts of kindness and blessing. Works include worship 'ghairi mahdah' (a relationship among creatures) as the command of God related to the work of QS. Al-An'am (6: 135), QS.At Taubah (9: 105) [10]. In Islam the personal nature of Muslims is honest (Shiddiq) QS. Az-Zumar (39:23), QS Ali-Imran (3:10), responsible (Amanah) QS Taha (16: 13-15), QS.Almaarij (29: 32-33), QS.Al -Hajj (17:41), intelligence (Fathonah) (QS.Az-Zumar 33-34)., As well as communicative (Tabligh) QS.Al-Ahzab (21:21). Thibaut and Kelly's [11] stated that organizational commitment will be achieved if there is a conformity of desire with the expectations of the organization, and it will affect the employee performance. Organizational commitment developed the theory of Meyer \& Allen [12] with affective, continuance, and normative commitment as the indicators.

There are six primary criteria to measure the employee performance: quality, quantity, timeliness, cost-effectiveness, the need for supervision, and interpersonal impact. The influence of organizational commitment to the employee performance can be explained that the quantity of the organizational commitment is reflected through the commitment of the sustainability by creating a good communication to support the employee performance, then, it will be reflected by the quantity of the work effort to meet the set targets. These criteria were developed by Mowday, et al. [14], Yousef [15], and Syauta et al. [16]. The influence of the Islamic work ethos encourages the improvement of the organizational commitment into very strategic improvement of the employee performance. Organizational commitment as an effective media to improve the employee performance. The Islamic work ethos becomes an alternative choice in an effort to increase the organizational commitment that more in line with the employee expectations. This study was adopted from a model developed by Meyer, Stanley and Herscovitch [17], Yousef [15], Chen [18] and Thibaut and Kelly [11].

\section{RESEARCH METHODS}

This research includes explanatory research type, by developing a survey method that using Likert scale questionnaire with the City government employees as the respondents. The data collected were tabulated and analyzed using confirmatory factor analysis and causality model of structural equation modeling. The population of this research is civil servant of the City Government, which entered in work unit and Moslem. The data were taken from January to April 2017 through a prepared questionnaire. The population of the study was 1,364 people, the samples were taken by using Slovin formula [20], with alpha $7 \%=178$ respondents [20]. The sampling technique used proportional random sampling, according to the proportion in each work unit. The characteristics of respondents age were approximately 49-54 years old that reflect psychological maturity, with a working length from 26-31 years. The data analysis techniques used in this study were confirmatory factor analysis and causality structural equation modeling (SEM), with the research hypothesis are:

H1: There is a significant influence of Islamic work ethos on the organizational commitment

H2: There is a significant influence of the organizational commitment on the employee performance

H3: There is a significant influence of Islamic work ethos on the employee performance

H4: There is a significant influence of Islamic work ethos on the employee performance through the organizational commitment

\section{RESULTS AND DISCUSSION}

\section{A. The Results of the Research}

This study consisted of exogenous variables of Islamic work ethos and endogenous variable of organizational commitment and employee performance. After the validity and reliability test of the research instrument were analyzed, the result showed the items of statement 1 to 14 employee performance variables yield $r$ value (grain correlation with total measured instrument) greater than cut-off value ( $\mathrm{r}$ table): 0.148 , it proved that the instrument is declared valid, and able to measure the indicator in question of the employee performance research instruments. The organizational commitment variable of the tabulated results shows that the items of the statement 1 to 9 produce the calculated $r$ value (grain correlation with the total measured instrument) greater than the cut-off value ( $\mathrm{r}$ table): 0.148 , it proved that the instrument is valid, and able to measure the indicator in this research instrument. The variable of Islamic work ethos statement 1 to 14 yields $\mathrm{r}$ value (grain correlation with total measured instrument) greater than cut-off value ( $\mathrm{r}$ table): 0.148 , it proved that the instrument is valid, and able to measure the indicator in the instrument of this study.

1) The results of confirmatory factor analysis of each research indicator were able to reflect the measured variables, that shows in the table 1 :

TABLE I. VALUE LOADING FACTOR ISLAMIC WORKING ETHOS

\begin{tabular}{lc}
\hline Indicator & Loading Factor \\
\hline Honest (Shidiq) (X1.1) & 0.56 \\
Responsible (Amanah) (X1.2) & 0.72 \\
Smart (Fathonah) (X1.3) & 0.76 \\
Communicative (Tabligh) (X1.4) & 0.81 \\
\hline & a. Source: Primary data, 2017
\end{tabular}

Based on table 1. The dominant Islamic work ethos is reflected by communicative indicator: 0.81 .

2) Organizational commitment variable, confirmatory factor analysis result of each indicator of the research were able to reflects the measured variable, see table 2 : 
TABLE II. VALUE LOADING FACTOR ORGANIZATIONAL COMMITMENT

\begin{tabular}{ll}
\hline Indicator & Loading factor \\
\hline Affective Commitment (y1.1) & 0.58 \\
Continuance Commitment (y1.2) & 0.91 \\
Normative Commitment (y1.3) & 0.68 \\
\hline & b. Source : Primer data, 2017
\end{tabular}

Based on table 2, the dominant organizational commitment is reflected by the Continuance commitment: 0.91 .

3) The mployee performance variable, confirmatory factor analysis result of each indicator of research were able to reflect the measured variable, see table 3 :

TABLE III. VALUE LOADING FACTOR EMPLOYERS PERFORMANCE

\begin{tabular}{ll}
\hline Indicator & Loading factor \\
\hline Quality (y2.1) & 0.62 \\
Quantity (y2.2) & $\mathbf{0 . 7 9}$ \\
Timeliness (y2.3) & 0.78 \\
Efectivity (y2.4) & 0.54 \\
Supervition (y2.5) & 0.70 \\
Interpersonal (y2.6) & 0.60 \\
\hline & c. Source : Primer data, 2017
\end{tabular}

Based on table 3, employee performance is dominantly reflected by quantity of work: 0.79 .

4) The conformity test structural equation modeling (SEM) result of fitness test of the goodness of fit model and statistic test can be seen on table 4.

TABLE IV.

FULL FIT MODEL SEM TEST RESULTS

\begin{tabular}{llll}
\hline $\begin{array}{l}\text { Goodness of Fit } \\
\text { Index }\end{array}$ & Cut off Value & $\begin{array}{l}\text { Results } \\
\text { Analysis }\end{array}$ & $\begin{array}{l}\text { Evaluation } \\
\text { Model }\end{array}$ \\
\hline Chi-Square & $<$ Chi-Square $\left(\mathrm{X}^{2}\right.$ & 158.133 & good \\
& table $)(\alpha=0.001 ;$ & & \\
& $\mathrm{DF}=220)=290.55$ & & good \\
Probability & $\geq 0,05$ & 0.091 & good \\
CMIN/DF & $\leq 2,00$ & 0.707 & good \\
GFI & $\geq 0,90$ & 0.930 & good \\
TLI & $\geq 0,95$ & 0.965 & good \\
NFI & $\geq 0,95$ & 0.961 & good \\
RMSEA & $\leq 0,08$ & 0.015 & \multicolumn{2}{c}{2017}
\end{tabular}

The result of fit model test shows chi square value: $158.133<$ from chi square table of 290.55 with sig $0.000<$ $\alpha=0.05$. This means that it has meet the criterion, the covariance matrix between the prediction and the actual observation is the same, so it can be concluded that there is no difference between the covariance matrix samples with the covariant matrices population and the model is accepted. While other results show that the value of CMIN / DF and RMSEA in accordance with the determined cutoff value is smaller according to the provisions, while GFI, TLI, NFI is greater than the value of the specified cut-off value so that it can be categorized as a fit model. The evaluation of goodness of fit criteria indicates that the constructed SEM model is acceptable, that is, the Islamic work ethos improves the employee performance through strategic organizational commitment role and effective mediation.
The hypothesis test results can be seen in the table 5:

TABLE V. RESULT OF HYPOTHESIS TEST

\begin{tabular}{|c|c|c|c|c|c|c|}
\hline & Dependent & & Independent & Estimate & c.r. & $\mathrm{P}$ \\
\hline H1 & $\begin{array}{l}\text { Organization } \\
\text { Commitment }\end{array}$ & $\leftarrow$ & $\begin{array}{l}\text { Islamic } \\
\text { Work Ethos }\end{array}$ & 0.13 & 4.23 & 0.00 \\
\hline $\mathrm{H} 2$ & $\begin{array}{l}\text { Employees } \\
\text { Performance }\end{array}$ & $\leftarrow$ & $\begin{array}{l}\text { Organization } \\
\text { Commitment }\end{array}$ & 0.31 & 2.33 & 0.02 \\
\hline $\mathrm{H} 3$ & $\begin{array}{l}\text { Employees } \\
\text { Performance }\end{array}$ & $\leftarrow$ & $\begin{array}{l}\text { Islamic } \\
\text { Work Ethos }\end{array}$ & 0.49 & 3.89 & 0.00 \\
\hline
\end{tabular}

Based on the hypothesis acceptance requirements, critical ratio value $(\mathrm{c} . \mathrm{r})>2$ and probability value $(\mathrm{p})<0.05: \mathrm{H} 1$. Islamic work ethos variable proved to have a significant effect on the organizational commitment, value c.r $=4.23$ with $\mathrm{p}$ : 0.00: H2. The organizational commitment variable proved to have a significant effect on the employee performance, c.r $=$ 2.33 with p: 0.02: H3. The Islamic work ethos variables proved to have a significant effect on the employee performance, c.r $=4.89$ with p: 0.00 . So, the hypothesis $1,2,3$ proves that the qualified acceptance of the hypothesis and has been tested. The fourth hypothesis (H4) can be seen based on direct, indirect and total influence. The hypothesis test result can be seen in the figure 1 .

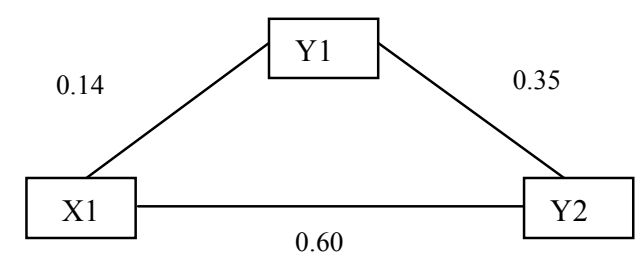

Fig. 1. The results of causality analysis

Information:

$$
\begin{array}{ll}
\mathrm{X}_{1} & =\text { Islamic work ethos } \\
\mathrm{Y}_{1} & =\text { Organizational commitment } \\
\mathrm{Y}_{2} & =\text { Employee performance }
\end{array}
$$

$$
\begin{aligned}
\text { Direct influence } & : \mathrm{X} 1 \rightarrow \mathrm{Y} 2=0.60 \\
\text { Indirect influence } & : \mathrm{X} 1 \rightarrow \mathrm{Y} 1 \mathrm{Y} 2 \\
& :(0.14 \times 0.35)=0.049 \\
\text { Total influence } & : 0.60+0.049=0.65
\end{aligned}
$$

Based on Figure 1 The variables of Islamic work ethos proved to have a significant effect on the employee performance through organizational commitment. The evaluation of goodness of fit criteria indicates that the constructed SEM model is acceptable, that is, the Islamic work ethos improves the employee performance through strategic organizational commitment role and effective mediation. 
Interestingly from the results of this study, the Islamic work ethos is effective in improving the employee performance.

\section{B. Discussion}

Based on the results of the research above, then the discussion is as follows:

\section{1) The influence of Islamic work ethos on the} organizational commitment

The organizational commitment will be more effective when the Islamic work ethos is carried out more intensively. The Islamic work ethos is described as a communicative (tabligh) competence with an effort to build the cooperation in harmony, this is based on what is stated in the holy Qur'an (QS al-Ahzab) (33:21) [10] "Indeed, there is in the Messenger of God a good example for you, that is for those who expect God's grace and the coming of the Hour and the remembrance of God. Prophet Muhammad invites cooperation as well as give examples to others to do the right things in life with one purpose to hope God's grace.”. QS Al-fath (48:18) [10] invites and gives us examples of correct communicative activities to build a cooperation to increase an organizational commitment. The Islamic work ethos reflected by communicative nature is sincerely executed, to create harmonious cooperation, to believe that working is a part of worship, and solely responsible for the blessing of God as its contribution. A sustainable commitment can be traversed by fostering the emotional and intellectual bonded feeling, with the creation of good communication ethos among employees and superiors.

In line with the study by Hayati and Caniago,[3] the Islamic work ethos has an effect on organizational commitment of Syariah bank employees in Bandar Lampung. Similarly, Salahudin et al.[4] applied the model to SME retail textile service in Selangor, Kuala Lumpur and Johor, and they found that the Islamic work ethos influences the organizational commitment and it able to help the workplace to achieve a large commitment among employees to the organization. The same study is done by Begum [5] which revealed that of 250 employees of conventional banks in Muzaffargarh, Layyah Rajan and Bahawalpur, i.e. that the Islamic work ethos has an influence on organizational commitment. Islamic work ethos forms the character, values and norms for a person or group according to Islamic belief, as the religion of "rahmatan lilallamin" (blessing for the whole world and its content) (Q.S. Al-Anbiya ', 21: 107) [10].

2) The influence of organizational commitment to the employee performance

The employee performance will be effective when the organizational commitment is intensively more executed, especially ongoing commitment, by upholding the ethics of the employee communication and superiors. Growing emotionally and intellectually attached feelings sustains employee performance. The findings of this study indicated that a positive organizational commitment sustains the improvement of the employee performance. The organizational commitment puts the moralist responsibility, the employees psychological bond to remain in the organization, loyal, proud and willing to achieve organizational goals. This research is in line with the theory of
Meyer and Allen [12] that the continuance commitment, directing the tendency of the employees not to leave the organization. Employee investment is the process of maintaining friendship, work relationships, with other fellow employees, and certain skills possessed. The research conducted by Mowday, et al. [14], and Yousef [15] found that the organizational commitment has a positive impact on the employee performance and their retention.

3) The influence of Islamic work ethos on the employee performance through organizational commitment.

The effective organizational commitment becomes a benchmark for aligning the Islamic work ethos to be a better guidance of the employee performance. The strategic position of organizational commitment fosters emotionally and intellectually bonded feelings within the organization, the employees have the sense of belonging to be part of the organization. Sustainability commitment by upholding the ethics of communication is good for the fellow employees and superiors. The employee performance will be effective when the Islamic work ethic is intensively more on the run. The Islamic work ethos is portrayed as a dominant by communicative nature through building harmonious cooperation. According to QS Al-Fath (48:18)[10] "Indeed, God has blessed the believers when they pledge to you under the tree, He knows what is in their hearts, then He gives them peace and rewards with a close victory. Man, who has done much good, invites and gives examples of true communicative activities in life and expect God's grace." The hadith of the Prophet stated that, "God loves His servant who works and is skilled. Whoever struggles for a living for his family, then he is like a mujahid in the way of God (hr : Ahmad) [10]. Islam does not want their people to work at random, lazy. A Work is worship, it is a part of the struggle of human dignity and people's economic degree. So, we must always work hard, discipline and responsible to improve our employee performance. In line with the research of Mitroff and Denton, [6] that the work ethos of Islam is more likely to improve the employee performance. Kale [7], Giacalone, Paul and Jurkiewicz [8], through the Islamic work ethos we will be more sensitive to the social performance, and the leaders will appreciate more to employee's work. Ali and Al Owaihan, [9] commented that Islamic work ethos has an economic-social and moral dimension to improve the employee performance. Similarly, Hayati and Caniago, [3] stated that the Islamic work ethos affects the performance of employees in Syariah Banks .

\section{CONCLUSION}

The Islamic work ethos is tested to influence the organizational commitment, if the Islamic work ethos is improved, then the organizational commitment is increased, by fostering emotional and intellectual attachment, through a good communication ethics of employees and superiors. Similarly, the organizational commitment with the employee performance was tested to give an effect. Organizational commitment reflected by the ongoing commitment will improve the employee performance. The Islamic work ethos with the employee performance is also tested to give an influence, through the communicative nature that reflects work ethos, and improve the employee performance in their 
work quantity to meet a set of targets. Organizational commitment as a mediating variable that in a strategic position, because it effectively mediates the Islamic work ethic of the employee performance. The works implementation as a part of worship is a hope of God's blessing, by improving employee performance as an organization's investment capital. For subsequent research, the value of honesty in tasks, investigation of work climate issues, work habits can be considered. The employee performance issues, related to the effectiveness of working innovatively, creatively, followed by efforts to increase organizational commitment, especially normative commitment in giving sanction for undisciplined employees for the city government to make continuous improvement with the anti-corruption movement, on time praying, anti-corruption material is included in the formal education curriculum from elementary school to university.

\section{REFERENCES}

[1] A. G. Agustian, Emotional Spiritual Quotient, ESQ, 53rd ed. Jakarta: Arga Publishing, 2010.

[2] K. Tasmara, Etos Kerja Pribadi Muslim. Yogyakarta: Dana Bhakti Wakaf, 1994

[3] K. H. d. I. Caniago, "The Role of Intrinsik Motivation, Job Satisfaction, Organizational Commitment and Job Performance," Procedia Sos. Behav. Sci., pp. 272-277, 2012.

[4] S. N. Salahudin, Baharuddin, S. Sarah, and Abdullah, "The Effect of Islamic Work Ethics on Organizational Commitment," Sci. Direct, Procedia Econ. Financ., vol. 35, pp. 582-590, 2016.

[5] B. Razia, "No TitleImpact of Islamic Work Ethics on Work Outcomes of Employees with Personality Conscientiousness as Moderator Variabel in the Banking Sector of Southern Punjab," J. Philos. Cult. Relig., vol. 12, pp. 52-60, 2015.

[6] I. I. Mitroff and E. A. Denton, A Islam Audit of Corporate America: Ten Years Later Islamity and Attachment Theory. San Fransisco: Jossey-Bass, 1999.

[7] S. Kale, "Spirituality, Religion, and Globalization," J. Macro Mark., pp. 92-107, 2004.

[8] R. A. Giacalone, P. K., and a. J. C. L, "A Preliminary Inverstigation into The Role of Positive Psychology in Consumer Sensitivity to Corporate Social Performance," J. Bus. Ethics, vol. 4, pp. 295-305, 2005.

[9] A. J. Ali and A.-O. Abdullah, "Islamic Work Ethic: A Critical review," Emerald Gr. Publ., vol. 1, pp. 5-19, 2008.

[10] K. A. RI, Al-Qur'an the Wisdom. Jakarta Selatan: PT Aku Bisa, 2013.

[11] H. J. K. Thibaut, The Social Exchange Theory. New York: John Wiley \& Sons, 1978.

[12] M. a. Allen and N. J., "A Three Component Concep Islamization of Organizational Commitment," Hum. Resour. Manag. Rev., vol. 61, pp. 20 52, 1991 .

[13] H. Bernardin and R. J. E.A., Human Resource Management, An Experiental Approach. Singapore: Singapore McGraw-Hill, 1993.

[14] R. T. Mowday, L. W. Porter, and R. M. Steers, "Employeeorganization Linkages: The Psychology of Commitment, Absenteeism, and Turnover Organizational and Occuptional Psychology,” Am. J. Sociol., vol. 88, pp. 1315-1317, 1983.

[15] D. Yousef, "Islamic Work Ethic: A Moderator Between Organizational Commitment and Job Satisfaction in A Cross-Cultural Context," Pers. Rev., vol. 30, pp. 152-169, 2001.

[16] J. H. Syauta, T. E. Afnan, S. Margono, and Solimun, "The Influence of Organizational Culture, Organizational Commitment to Job Satisfaction and Employee performance,” Int. J. Bus. Manag. Invent., vol. 1, pp. 69-76, 2012.
[17] M. JP. and H. L., "Commitment in The Workplace: Toward a General Model,” Hum. Resour. Manag. Rev., vol. 11, no. 3, pp. 299-326, 2001.

[18] A. Chen and L. Yueh, "No TitleExamining The Effect of Organization Culture and Leadership Behaviors on Organizational Commitment, Job Satisfaction at Small and Middle-Sized Firms of Taiwan," J. Am. Acad. Bus., vol. 5, pp. 432-438, 2004.

[19] R. E., Membangun Pertautan Syariah Kaitannya dengan Peningkatan Kinerja Karyawan Perbankan Syariah di Kota Semarang. Semarang, 2013.

[20] A. Sanusi, Metode Penelitian Bisnis. Jakarta Selatan: Salemba Empat, 2013. 